Original Research Paper

\title{
Peningkatan Kemampuan Apresiasi Sastra Untuk Siswa SMA Negeri 1 Praya Lombok Tengah
}

\author{
Nuriadi $^{1}$, Baharudin ${ }^{1}$, M. Isnaini ${ }^{1}$, M. Fadjri ${ }^{1}$ \\ ${ }^{1}$ Program Studi Pendidikan Bahasa Inggris, Fakultas Keguruan dan Ilmu Pendidikan, Universitas Mataram
}

https://doi.org/10.29303/jpmpi.v3i2.608

Sitasi: Nuriadi., Baharudin., Isnaini, M., \& Fadjri, M. (2021). Peningkatan Kemampuan Apresiasi Sastra Untuk Siswa SMA Negeri 1 Praya Lombok Tengah. Jurnal Pengabdian Magister Pendidikan IPA, 4(1)

\section{Article history}

Received: 05 Desember 2020

Revised: 30 Desember 2020

Accepted: 29 Januari 2021

*Corresponding Author:

Nuriadi, Program Studi

Pendidikan Bahasa Inggris,

Fakultas Keguruan dan Ilmu

Pendidikan, Universitas

Mataram.

Email: nuriadi@unram.ac.id

\begin{abstract}
Makalah ini ditulis berdasarkan kegiatan pengabdian yang dilangsungkan di SMA Negeri 1 Praya, Kabupaten Lombok Tengah pada Sabtu, 26 September 2020. Kegiatan ini berupa penyuluhan dengan sasaran siswa-siswa jurusan Bahasa dan Budaya dan guru-guru bahasa. Pembicaranya adalah Dr. H. Nuriadi S.S., M.Hum., Drs. Baharudin, M.Hum., M. Isnaini, MA., dan Dr. M. Fadjri, MA. Ditemukan bahwa kegiatan ini dipandang mempunyai manfaat yang cukup berarti yaitu diperolehnya pengetahuan baru terkait dengan sastra, yang mana materi tersebut bisa menjadi "wahana" mereka dalam mempelajari mata pelajaran bahasa dan sastra di dalam kelas serta juga bisa dimanfaatkan dalam meningkatkan kegiatan ekstrakurikuler terkait pemajuan literasi di sekolah tersebut. Selain itu, dengan adanya apresiasi, karya sastra tidak hanya berfungsi sebagai hiburan (dulce) saja tetapi juga sebagai media untuk memperoleh pelajaran (utile). Semua peserta menyetujui pandangan tersebut karenanya mereka semakin terdorong untuk membaca dan mengapresiasi sastra.
\end{abstract}

Keywords: Apresiasi sastra; Pengabdian masyarakat; Penyuluhan.

\section{Pendahuluan}

Karya sastra merupakan obyek estetis (aesthetic object) yang mana tidak mempunyai fungsi dan makna yang jelas dan kontributif apabila tidak dimaknai atau diapresiasi oleh pembacanya. Pembacalah menjadi aktor utama sebuah karya sastra sehingga bisa bermakna dan memberi pembelajaran bagi kehidupan manusia. Karya sastra hanya sekadar, dalam pandangan strukturalis, sebagai sebuah 'benda mati' (artefact) yang nyatanyata di dalamnya terorganisir dengan dirinya sendiri, yang pada dasarnya tidak mampu berbicara ke publiknya tanpa melibatkan keaktifan dan kreatifitas pemikiran pembacanya. Dengan demikian, dalam konteks pembelajaran sastra di tingkat sekolah menengah atau atas, pengajaran sastra tidak bisa berkembang baik dari segi pemikiran maupun afektifitas pada peserta didik, apabila para gurunya tidak memposisikan diri mereka sebagai pembaca yang aktif dan kreatif.

Dalam konteks ini, para guru itu seharusnya mampu memposisikan dirinya sebagai aktor utama (pivot actor) di dalam mentransformasikan nilai, pesan, dan makna karya sastra ke dalam relung pikiran dan bathin peserta didik mereka. Mereka harus mampu mengubah posisi karya sastra dari karya artefak menjadi obyek estetis, sehingga akibatnya dapat berdampak lebih kontributif bagi peserta pembelajaran sastra itu sendiri baik ketika di sekolah maupun setelah berada di masyarakat.

Di samping itu, pembelajaran sastra merupakan salah satu pembelajaran yang mempu menciptakan manusia-manusia yang berkarakter, bermartabat, dan peka terhadap realitas-realitas sosial. Melalui pembelajaran sastra, peserta didik tidak saja diberikan kecerdasan intelektual sastra saja tetapi juga dibekali dengan kecerdasan 
emosional atau bathiniah yang mumpuni sehingga para peserta didik nantinya akan mampu menempatkan diri sebagai pribadi yang dapat dicontoh di lingkungan tempat mereka berada. Pemerintah, melalui PP No. 19/2005 Pasal 26 Ayat 1-2, menyatakan bahwa pembelajaran sastra bertujuan untuk meletakkan dan mengembangkan akhlak mulia peserta didik (Rivai dalam Sylvani, 2009: 36). Sejalan dengan itu, Mahayana (2007: 2) mengemukakan bahwa:

Pembelajaran sastra di sekolah akan menjadi wadah bagi siswa (a) menikmati dan memanfaatkan karya sastra untuk memperluas wawasan, memperhalus budi pekerti, serta meningkatkan pengetahuan dan kemampuan berbahasa, dan (b) menghargai dan membanggakan sastra Indonesia sebagai khazanah budaya dan intelektual manusia Indonesia. Hadirnya sastra sebagai materi ajar dan bahhan bacaan di sekolah adalah awal yang baik untuk apresiasi sastra untuk siswa sebelum terlibat sebagai penggubah karya sastra di masa mendatang.

Sehubungan dengan hal ini, akan tetapi sejauh ini, pembelajaran sastra di tingkat sekolah khususnya Sekolah Menengah Atas (SMA) atau Sederajat (SMK atau MA) cenderung dianggap kurang begitu menarik dan tidak dipandang kontributif di dalam meningkatkan kemampuan bahasa dan kekayaan batin peserta didik. Padahal, di tingkat sekolah SMA atau SMK atau MA itu pembelajaran sastra tidak hanya diarahkan pada identifikasi apa, siapa, kapan saja, tetapi sudah mulai diarahkan pada konteks menjawab bagaimana dan mengapa, meskipun memang tidak mendalam. Apabila hal tersebut dilaksanakan dengan baik dan nyaman tentunya, maka pengajaran sastra akan lebih menarik dan bermanfaat sekali. Mengapa demikian? Hal ini disebabkan pembelajaran sastra dilaksanakan dengan "cara begitu-begitu" saja (business as usual) dan terkooptasi dengan hal-hal yang sudah diarahkan oleh buku teks ataupun yang lainnya. Akibatnya, pengajaran sastra menjadi membosankan dan sudah bisa ditebak. Dengan kata lain, pengajarannya tidak inspiratif ataupun mengafeksi pesera didik untuk 'terlibat' lebih jauh di dalam menghayati nilai atau pesan yang ditawarkan oleh karya sastra yang diajarkan. Hal ini disebabkan, salah satunya, karena faktor pengajarnya sendiri yang nota bene berperan sentral di dalam menstranformasi makna dan pesan karya sastra itu. Guru dalam hal ini sebagai pembaca utama atau subyek kunci di dalam kegiatan tersebut. Guru, dengan demikian, mau tidak mau harus meningkatkan kemampuannya di dalam mengapresiasi karya sastra. Kemampuan meliputi pengetahuan umum tentang kehidupan maupun pengetahuan khusus berupa teori-teori sastra yang menjadi "alat pisau" (theoretical framework) dalam mengapresiasi sastra.

Oleh karena itu, dipandang perlu untuk melakukan semacam penyuluhan dan/atau pelatihan singkat terkait dengan peningkatan kemampuan apresiasi karya sastra bagi siswa-siswa yang secara khusus belajar tentang bahasa dan sastra di tingkat sekolah menengah atas (SMA) atau yang Sederajat (SMK/MA). Siswa-siswa yang dimaksud adalah mereka yang masuk Jurusan Bahasa dan Budaya. Sehubungan dengan hal ini, kegiatan pengabdian dapat dilaksanakan di SMA Negeri 1 Praya Lombok Tengah Kabupaten Lombok Tengah pada tanggal 26 September 2020.

Tentu, dengan adanya penyuluhan terkait peng-apresiasi-an karya sastra tersebut, siswasiswa, termasuk guru-guru bahasa di sekolah tersebut, bisa mempunyai "pengetahuan baru' dan atau pengalaman baru dalam memandang dan mengkaji karya sastra. Mereka, dalam hal ini, merupakan calon krtitikus dan pemberi makna terhadap karya sastra yang sebenarnya jika tidak diapresiasi maka akan menjadi artefak atau benda mati saja. Padahal jika diapresiasi dan dicintai, pembelajaran yang terkait dengan pembentukan karakter generasi muda, seperti dicanagkan pemerintah melalui prgram Pendidikan Karakter, secara alami dapat berjalan secara lebih mudah dan efektif. Hal ini disebabkan karya sastra berposisi sebagai sebagai sumber inspirasi dan sekaligus berperan sebagai salah satu wahana untuk penanaman nilai dan karakter bangsa. Dengan demikian, sekali lagi, kegiatan untuk melakukan upaya peningkatan kemampuan apresiasi sastra dipandang perlu dan menarik untuk diselenggarakan di sekolah menengah atas dengan target potensialnya adalah para siswa, yang dianggap masih labil dan sedang mencari karakternya.

\section{Metode}

Kegiatan pengabdian ini dilangsungkan di SMA Negeri 1 Praya, Kabupaten Lombok Tengah 
pada hari Sabtu, 26 September 2020 selama tiga jam. Kegiatan ini berupa penyuluhan dengan sasaran siswa-siswa jurusan Bahasa dan Budaya. Namun, karena kegiatan ini dipandang cukup strategis dan bermanfaat, maka sasaran kegiatan ini meluas tidak hanya untuk siswa-siswa jurusan Bahasa dan Budaya saja, tetapi termasuk juga para guru bahasa dan sejumlah perwakilan dari siswa yang sejauh ini mempunyai minat besar pada literasi karya sastra. Keputusan ini diambil oleh Kepala Sekolah SMA tersebut, Bapak Drs. H. M. Amrullah, MM. Oleh karena itu dihadiri lebih dari tiga puluhan orang, dan memenuhi Aula atau ruang pertemuan sekolah menengah tersebut, di lantai dua.

\section{Hasil dan Pembahasan}

\section{Proses Kegiatan Pengabdian di SMAN 1 Praya}

Keberlangsungan kegiatan pengabdian ini berawal dari jalinan komunikasi yang cukup baik di antara para pengabdi, para dosen Prodi Pendidikan Bahasa Inggris, khususnya Ketua Pengabdian Dr. Nuriadi S.S., M.Hum, dengan dua guru bahasa di sekolah tersebut, yaitu Pak Hapazah Bukhari, M.Pd. dan Bu Nurmiana, M.Pd, yang keduanya ternyata alumni dari Pasca Bahasa di FKIP Universitas Mataram. Jalinan komunikasi ini mengarah pada pelaksanaan kegiatan pengabdian ini. Namun sebelum pelaksanaannya, ketua pengabdian datang menemui kepala sekolah SMA untuk meminta pendapat, arahan, dan persetujuan beliau selaku orang yang menjadi top leader di sekolah tersebut. Kepala sekolah itu kemudian secara langsung menerima dan menyetujui pelaksanaan pengabdian tersebut hingga ditentukan waktu, hari, dan tanggal pelaksanaannya. Bahkan tidak hanya itu, kepala sekolah juga meminta kedua guru (yang saya sebut di atas) untuk melakukan koordinasi dan memperluas sasaran kegiatan pengabdian tersebut.

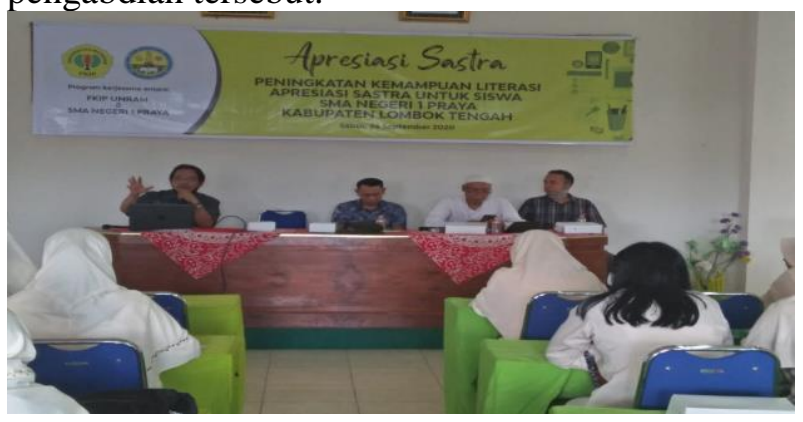

Gambar 1. Suasana Kegiatan Pengabdian
Kegiatan Pengabdian ini berwujud penyuluhan atau pengadaan seminar setengah hari dengan tajuk Literasi Apresiasi Sastra. Yang menjadi pembicara adalah semua dosen yang melakukan pengabdian yaitu Dr. H. Nuriadi S.S., M.Hum., Drs. Baharudin, M.Hum., M. Isnaini, MA., dan Dr. M. Fadjri, MA. Keempat pembicara ini mengangkat tema atau isu yang berbeda-beda, yang memang sudah ditentukan sebelumnya. Nuriadi berbicara tentang apa karya sastra dan bagaimana cara mengapresiasinya; Baharudin berbicara tentang manfaat membaca dan mengapresiasi karya sastra; M.Isnaini berbicara tebtang karakteristik bahasa ekspresi karya-karya sastra, dan M. Fadjri berbicara terkait sejauh mana peran sastra di dalam membangkitkan literasi bagi masyarakat, khususnya bagi kaula muda. Kegiatan pengabdian ini berlangsung dengan sangat lancar, meriah, dan menyenangkan. Terlebih, di sela-sela acara, para guru dan siswa memberi kontribusi pembacaannya pada karya puisi yang sudah diketahuinya sebelumnya. Lebih jelasnya, kegiatan pengabdian ini bisa disaksikan/ditonton di saluran Youtube: htttps//youtu.be/PMGeZ55yWI, Youtube resmi SMA Negeri 1 Praya.

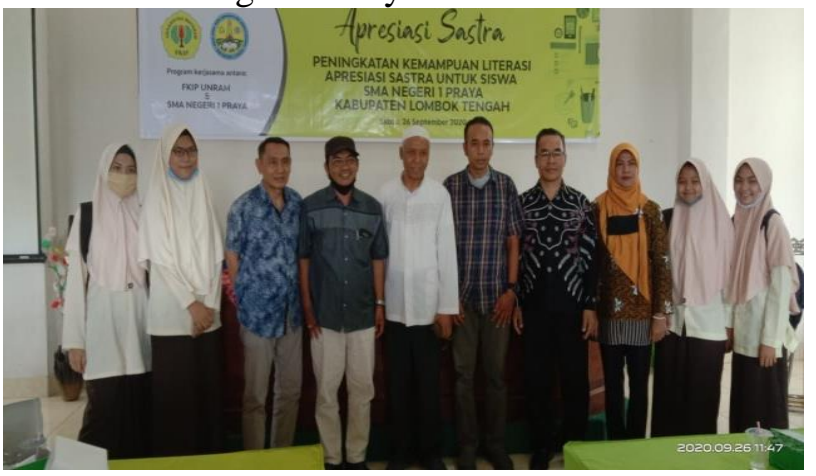

Gambar 2. pose setelah acara penyuluhan selesai

Seperti yang diutarakan di atas, kegiatan pengabdian ini berbentuk penyuluhan, yang mana keempat pembicara memberikan materi-materinya ke audiens, dengan menayangkan materi berupa power point. Maisng-masing pembicara diberi waktu 15 sampa dengan 20 menit. Lalu setelah itu, diberi waktu untuk tanya jawab di antara pembiara dan peserta. Dalam sesi inilah, muncul pengakuan atau apresasi secara jujur dari para peserta yang merasa tercerahkan dan memperoleh pengetahuan yang baru terkait karya sastra, cara mengapresiasi serta kemanfaatannya bagi kehidupan manusia. Di antara manfaatnya adalah sastra dapat membuka mata batin atau kepekaan untuk melihat realitas dan 
kebenaran serta dapat pula meningkatkan literasi dan menjadi wahana untuk membangun karakter bangsa. Dengan demikian, secara tidak langsung, sastra mempunyai peran yang esensial bagi masyarakat, selain tentu menambah pemahaman dalam praktik berbahasa.

Dengan demikian, penyuluhan ini dipandang mempunyai manfaat yang cukup berarti bagi siswa-siswa yang ada di sekolah tersebut, yaitu diperolehnya pengetahuan baru terkait dengan sastra, yang mana materi tersebut bisa menjadi "wahana" mereka dalam mempelajari mata pelajaran bahasa dan sastra di dalam kelas, serta juga bisa dimanfaatkan dalam meningkatkan kegiatan ekstrakurikuler terkait pemajuan literasi di sekolah tersebut. Dalam konteks ini, pengabdian tersebut dapat dipandang berhasil.

\section{Sastra dalam konteks Apresiasi dan Literasi}

Karya sastra itu adalah karya kreatif yang artistik dengan menggunakan bahasa lisan dan tulisan sebagai medianya (Nuriadi, 2016: 3). Dikatakan kreatif karena ia muncul sebagai wujud kreasi yang original datang dari dalam diri seseorang yang disebut penulis atau sastrawan. Ia muncul dengan melibatkan kombinasi pikiran dan emosi demi memunculkan "kebenaran" menurut dirinya. Kebenaran yang bersifat jujur karena sesungguhnya datang dari hati nurani. Ia muncul terurai bagaikan butiran-butiran ilham hanya dengan rangkaian bahasa. Bahasa-lah yang menimbulkan efek estetis dalam diri pembacanya. Bahasa-lah yang menimbulkan makna dalam benak dan jiwa penikmatnya. Bahasa-lah yang menjadikan tulisan bernama sastra itu mengungkapkan kedalaman filosofi, ideologi, pesan, dan nilai pengarangnya. Bahasa-lah yang menjadikannya berubah tak ubahnya seperti lukisan yang indah atau bagaikan simfoni musikal yang syahdu. Bahasa-lah yang menjadikan karya itu bisa dinamakan sastra. Bahasa-lah yang menggugah dan mengafeksi pembacanya. Benar, karya sastra ada karena ada bahasa. Oleh karena itu, berbicara sastra tentu sekali berarti sang pengarang tengah memainkan "bahasa" sebagai properti yang memaknai semua maksudnya. Dengan demikian, tidaklah salah bila Robert Frost berkata sastra itu adalah penampilan atau pertunjukan dalam katakata (Barnet, 1961: 1). Intinya, Karya sastra itu adalah karya SENI! Seni karena tercipta secara artistik dan menimbulkan efek estetis.
Istilah 'sastra' berasal dari bahasa Sanskerta, sementara istilah literature, sebagai padanan sastra dalam bahasa Inggris berasal dari bahasa Latin, litteratura. Kata 'sastra' berasal dari dua akar kata sas yang berarti mengarahkan, mengajar, memberi petunjuk, dan instruksi. Akhiran tra berarti alat, sarana. Jadi, secara leksikal sastra berarti kumpulan alat untuk mengajar, buku petunjuk atau buku pangajaran yang baik silpasastra (buku petunjuk arsitektur), kamasastra (buku petunjuk percintaan). Dalam perkembangan berikut kata sastra dikombinasikan dengan awalan 'su', sehingga menjadi susastra, yang diartikan sebagai hasil ciptaan yang baik dan indah. Dalam teori kontemporer sastra dikaitkan dengan ciri-ciri imajinasi dan kreativitas, yang selanjutnya merupakan satu-satunya ciri khas kesusastraan (Ratna, 2007:4; Nuriadi, 2016: 8).

Karena ciri karya sastra yang berpangkal tolak pada imajinasi dan kreativitas (creatio) inilah, maka sastra atau kesusasteraan masuk atau digolongkan menjadi karya seni (a work of art), tidak lebih dari karya-karya lukisan, patung, serta wujud karya seni yang lain, kendatipun memang landasan penciptaannya tetap pada realitas-realitas manusia yang ada (imitatio). Akan tetapi, yang membedakannya dengan karya seni yang lain adalah media ungkapnya saja, yaitu bahasa. Oleh karenanya sastra adalah karya seni imajinatif dan kreatif yang menggunakan bahasa (language) sebagai media ekspresinya. Pandangan ini tidaklah salah karena dalam proses penciptaan atau proses artistik sebuah karya sastra, seorang pengarang senantiasa melibatkan daya kreatif dan imajinatifnya sehingga hasil ciptaannya itu menjadi menarik, inspiratif, di samping bermakna dan bermanfaat bagi kemanusiaan manusia. Dalam tataran ini, sastra sejatinya terlingkupi oleh dua konsep yang disebutkan oleh Horatius, dulce dan utile (Siswanto, 2008: 87), yang berarti karya sastra harus bisa menghibur, menyenangkan, dan menimbulkan aspek estetis pada audiensnya (dulce) di samping itu memberi pembelajaran dan kemanfaatan bagi penikmatnya (utile).

Oleh karena itu, dalam konteks cara mengapresiasinya, karya sastra harus didekati dan dijiwai terlebih dahulu dengan cara, konkritnya, dibaca dan dipahami dengan sebaik-baik nya. Jika tidak demikian, karya sastra hanya sebatas bacaan biasa dan tidak bisa memberi nilai tambah dalam arti kemanfaatan lebih bagi masyarakat. Maka dari 
itu, hal yang harus dilakukan pembaca dalam mengapresiasi karya sastra adalah: 1 . Membaca, 2. Memahami 3. Mengkaji 5. Merefleksi dan 6. Mengkonkretisasinya. Kesemuanya ni menjadi satu rangkaian kerja yang berjalan secara sambungsinambung dalam konteks melakukan kegiatan mengapresiasi tersebut. Memang secara bahasa, mengapresiasi dapat diartikan sebagai kegiatan yang mengarah pada bagaimana keberadaan sebuah karya sastra bisa diakui dan dihargai (Hornby, 1974). Namun, tidak hanya demikian, jika dilihat dari segi praktiknya, di mana mengapresiasi merupakan kegiatan dalam rangka memaknai dan menunjukkan kemanfaatnnya dalam ilmu pengetahuan, pembangunan karakter dan peradaban, serta dalam rangka menjadi rekaman atas kemajuan sebuah masyarakat.

Berbicara lebih jauh tentang karya sastra, bahwa karya sastra tidak hanya meliputi work of art seperti novel, cerpen, puisi, dan drama saja, tetpi juga meliputi tulisan kreatif lain yang bersifat nonfiktif seperti esai, biografi, autobiografi, surat, khotbah, resensi, dan memoir. Semua itu, dalam penciptaannya secara artistik, melibatkan kekuatan bathin, kemampuan pikiran, pengetahuan, di samping imajinasi dan ketajaman rasa dari pengarangnya. Dalam konteks ini, karya sastra kemudian tidak keluar dari "ruang kosong" yang mana penciptaannya berkaitan realitas konteks dan hal lainnya. Dengan demikian, karya sastra kemudian menjadi satu dunia yang bisa dibedah dan dimaknai tergantung kedalaman pengetahuan dan pemahaman pembacanya sebagai pelaku apresiasi.

Sehubungan dengan hal ini, karya sastra dapat diapresiasi dari segi bahasanya, dari segi keterkaitannya dengan dunia bathun dan prinsip kehidupan pengarangnya, keterkaitannya dengan realitas politik dan sosial-budaya di mana karya itu muncul, serta terkait afeksi dan pragmatiknya dalam kehidupan masyarakat di era terkini. Semua itu penting untuk dikaji sehingga karya sastra bisa menjadi "alat" membangun karakter dan peradaban serta pengetahuan zaman para pembacanya. Lebih jelasnya, lihat gambar berikut:

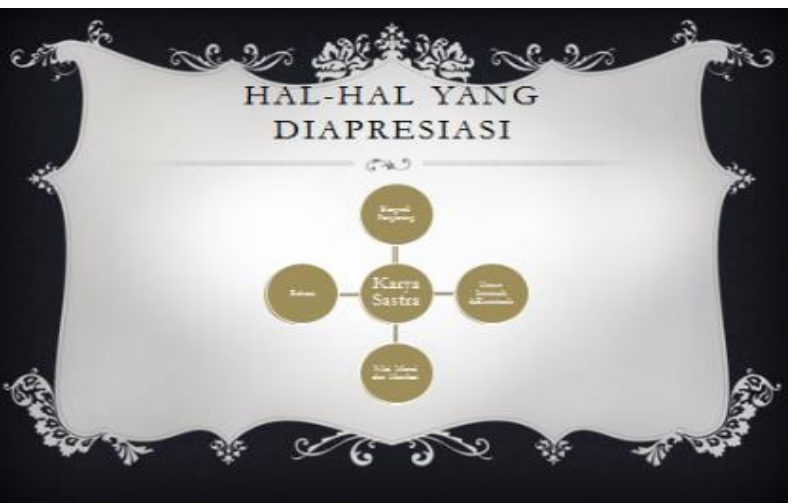

Gambar 3. Materi yang diapresasi

Dalam konteks cara mengapresiasinya, karya sastra harus didekati dan dijiwai terlebih dahulu dengan cara, konkritnya, dibaca dan dipahami dengan sebaik-baik nya. Jika tidak demikian, karya sastra hanya sebatas bacaan biasa dan tidak bisa memberi nilai tambah dalam arti kemanfaatan lebih bagi masyarakat. Maka dari itu, hal yang harus dilakukan pembaca dalam mengapresiasi karya sastra adalah: 1. Membaca, 2. Memahami 3. Mengkaji 5. Merefleksi dan 6. Mengkonkretisasinya. Kesemuanya ini menjadi satu rangkaian kerja yang berjalan secara sambungsinambung dalam konteks melakukan kegiatan mengapresasi tersebut. Memang secara bahasa, mengapresiasi dapat diartikan sebagai kegiatan yang mengarah pada bagaimana keberadaan sebuah karya sastra bisa diakui dan dihargai. Namun, tidak hanya demikian, jika dilihat dari segi praktiknya, di mana mengapresiasi merupakan kegiatan dalam rangka memaknai dan menunjukkan kemanfaatnnya dalam ilmu pengetahuan, pembangunan karakter dan peradaban, serta dalam rangka menjadi rekaman atas kemajuan sebuah masyarakat.

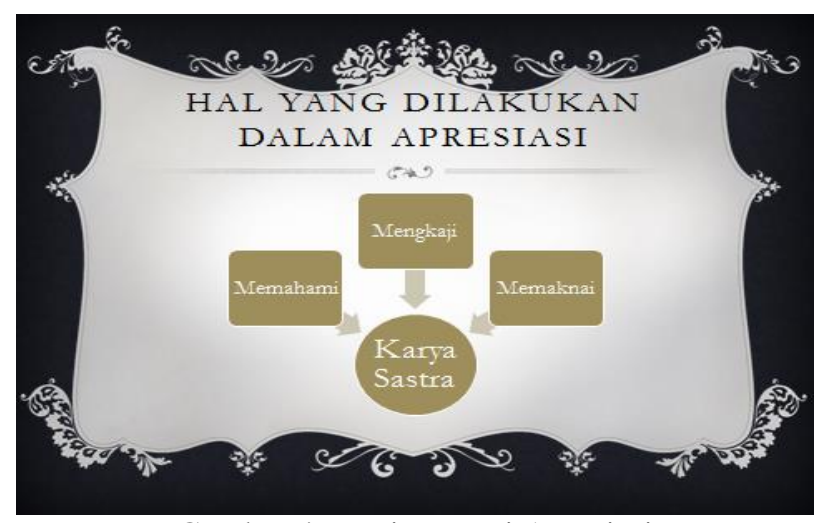

Gambar 4. Kegiatan Inti Apresiasi 
Ketika hal ini mampu dilakukan, maka pembaca sebenarnya sedang meningkatkan kemampuan literasinya dan memperkaya bathinnya. Pembaca telah mampu dan menyadari sastra bisa menjadi "lampu" dan "cermin" bagi masyarakatnya, seperti yang dikatakan oleh M.H. Abrams. Selain itu, ketika hal ini dilaksanakan, maka pembaca sedang menjadikan karya sastra sebagai media pembelajarannya untuk mengetahui dunia dan tujuan hidupnya sebagai manusia. Mengapa demikian? Karena karya sebenarnya menyajikan "kebenaran" ddengan cara yang berbeda. Misalnya, ketika seseorang membaca karya-karya novel Pramoediya Ananta Toer, maka dia sedang membaca bagaimana peradaban orang Indonesia di masa lampau terutama pada era penjajahan Belanda. Dia juga akan mendapat pelajaran bahwa apapun bentuk penjajahan, sesungguhnya penjajahan selalu menindas dan menihilkan kebebasan manusia. Penjajahan adalah penindasan manusia yang lemah dan bodoh. Bahkan penjajahan adalah pembodohan itu sendiri. Jika ini tercapai dalam proses pembacaan dan apresiasi, maka terjadilah tingkat literasi yang tinggi bagi diri pembaca.

\section{Kesimpulan}

Dari uraian di atas, dapatlah dikatakan sebagai simpulan bahwa kegiatan pengabdian ini dilangsungkan di SMA Negeri 1 Praya, Kabupaten Lombok Tengah pada hari Sabtu, 26 September 2020 selama tiga jam. Kegiatan ini berupa penyuluhan dengan sasaran siswa-siswa jurusan Bahasa dan Budaya dengan tajuk Literasi Apresiasi Sastra. Pembicaranya adalah Dr. H. Nuriadi S.S., M.Hum., Drs. Baharudin, M.Hum., M. Isnaini, MA., dan Dr. M. Fadjri, MA. Keempat pembicara ini mengangkat tema yang berbeda.

Dalam konteks cara mengapresiasinya, karya sastra harus didekati dan dijiwai terlebih dahulu dengan cara, konkritnya, dibaca dan dipahami dengan sebaik-baik nya. Jika tidak demikian, karya sastra hanya sebatas bacaan biasa dan tidak bisa memberi nilai tambah dalam arti kemanfaatan lebih bagi masyarakat. Maka dari itu, hal yang harus dilakukan pembaca dalam mengapresiasi karya sastra adalah: 1. Membaca, 2. Memahami 3. Mengkaji 5. Merefleksi dan 6. Mengkonkretisasinya. Kesemuanya ni menjadi satu rangkaian kerja yang berjalan secara sambung- sinambung dalam konteks melakukan kegiatan mengapresasi tersebut. Memang secara bahasa, mengapresiasi dapat diartikan sebagai kegiatan yang mengarah pada bagaimana keberadaan sebuah karya sastra bisa diakui dan dihargai. Namun, tidak hanya demikian, jika dilihat dari segi praktiknya, di mana mengapresiasi merupakan kegiatan dalam rangka memaknai dan menunjukkan kemanfaatnnya dalam ilmu pengetahuan, pembangunan karakter, serta dalam rangka menjadi rekaman kemajuan sebuah masyarakat.

Akhirnya, penyuluhan ini dipandang mempunyai manfaat yang cukup berarti bagi siswasiswa yang ada di sekolah tersebut, yaitu diperolehnya pengetahuan baru terkait dengan sastra, yang mana materi tersebut bisa menjadi "wahana" mereka dalam mempelajari mata pelajaran bahasa dan sastra di dalam kelas, serta juga bisa dimanfaatkan dalam meningkatkan kegiatan ekstrakurikuler terkait pemajuan literasi di sekolah tersebut. Dalam konteks ini, pengabdian tersebut dapat dipandang berhasil. Oleh karena itu, disepakati lebih lanjut supaya kegiatan semacam ini bisa dilanjutkan di waktu mendatang dalam bentuk kerja sama secara resmi antara SMA Negeri 1 Praya dengan Prodi Pendidikan Bahasa Inggris FKIP Unram.

\section{Ucapan Terima Kasih}

Terima kasih yang tidak terhingga kami sampaikan kepada Rektor Universitas Mataram c.q. Ketua LPPM Unram atas pembiyaan Pengabdian ini melalui dana PNBP 2020. Ucapan terima kasih juga disampaikan kepada Dekan FKIP Unram atas semua ijin dan fasilitasi yang diberikan sebelum dan selama proses Pengabdian tersebut berlangsung. Terima kasih sebesar-besarnya disampaikan pula kepada SMA Negeri 1 Praya atas kerja samanya sehingga akhirnya acara pengabdian dapat terlaksana sesuai rencana. Artikel ini merupakan hasil/luaran dari ikhtiar kami yang didukung oleh banyak pihak, termasuk guru-guru dan para peserta didik SMA Negeri 1 Praya. Tanpa mereka kegiatan itu tidak bisa berjalan. Untuk ini diucapkan banyak terima kasih pula.

\section{Daftar Pustaka}

Barnet, Sylvan et al. 1963. An Introduction to Literature: Fiction, Poetry, Drama. Second 
edition. Boston: Little, Brown and Company.

Budiningsih, C.A. 2005. Belajar dan Pembelajaran. Jakarta: Renika Cipta.

Hornby, AS. 1974. Oxford Advanced Learner's Dictionary of Current English. Revised and Updated. Oxford: Oxford University Press.

Mahayana, Maman. 2007. "Apresiasi Sastra di Sekolah" http://johnherf.wordpress. Com/2007/02/07/bahasa-dan-sastraindonesia-di-sekolah. Diakses 11 Maret 2015.

Nuriadi. 2016. Theory of Literature: An Introduction. Mataram: Arga Puji Press.

Ratna, Nyoman Kutha. 2007. Sastra dan Cultural Studies: Representasi Fiksi dan Fakta. Cetakan kedua. Yogyakarta: PT. Pustaka Pelajar.

Rivai, Veithzal dan Sylviana Murni. 2009. Education Management: Analisis Teori dan Praktik. Jakarta: Rajawali Press.

Siswanto, Wahyudi. 2008. Pengantar Teori Sastra. Jakarta: Penerbit PT Grasindo 